\title{
Memórias femininas: tempo de viver, tempo de lembrar
}

Feminine memories: a time for living, a time for remembering

Vanessa Ribeiro Simon Cavalcanti*

\section{RESUMO}

Enveredar pelo universo feminino católico entre as décadas de 1920 e 1940 é o objetivo deste artigo, descortinando as representações de mulheres a partir de suas memórias e egodocumentos. A análise de instituição de ensino confessional proporciona matizes da vida cotidiana e da identidade construída socialmente, revelando o cumprimento de papéis funcionais e de modelos a serem seguidos como exemplo de família, valores e qualificação.

Palavras-chave: História; memória; mulheres; família.

\section{ABSTRACT}

The objective of this article is to direct our footsteps through the Catholic feminine milieu between 1920 and 1940, revealing the testimonies of women from their memoirs and personal documents. An analysis of the institution of convent schooling exposes the nuances of everyday life and of a socially constructed identity, emphasizing the filling of functional roles and role models as examples of family, values and qualification. Keywords: History; memory; women; family.

\footnotetext{
* Universidade Católica do Salvador / Centro de Estudios Brasileños de la Universidad de Salamanca (España). Rua Alberto Valença, 114, ap. 1304, ed. Torre Toscana. 41810-825 Salvador - BA - Brasil. vanessa.cavalcanti@uol.com.br.
} 
Recordar é acordar a memória.

Maria da Conceição Jardim, ex-aluna de Sion

Na realidade, não há percepção que não esteja impregnada de lembranças.

Henri Bergson

\section{O PERCURSO DA MEMÓRIA: POVOANDO O PASSADO}

As minhas lembranças não datam de tão longe. São velhas, porém, são velhíssimas, dirão as pessoas de hoje. Concordo que o sejam. Parecem-me, por vezes, de ontem, tão frescas, vivas e buliçosas se conservaram, imorredouramente, em mim. Tenho por elas o carinho emocionado da criança pelos seus bonecos. São os brinquedos da minha saudade ... O meu velho Sion ... Não sei se todas o verão como eu o via. Sei, porém, quando, no desencanto e na experiência da minha maturidade, uma onda maior de ceticismo e de amargor ameaça submergir-me toda crença e toda esperança, é para a capelinha deste passado Sion, agora mudado, transformado, engrandecido e modernizado, que, insensivelmente, me volto ... Um perfume de incenso erra no ar, as flores do altar se esbatem numa penumbra cheia de unção, no alto, a Virgem de Sion apruma o vulto claro sobre as procelas do mundo. IN SION FIRMATA SUM. Crer. Esperar. Amar. Foi de ontem. É de hoje ainda. Será de sempre. ${ }^{1}$

Invocações que parecem recentes pertencem, de fato, a tempos muito velhos. Lembranças de dias antigos se misturam inapelavelmente nos acontecimentos de ontem, de hoje, até mesmo nos de amanhã. Que tempos são esses, os tempos da memória?

Nas reminiscências de Maria Eugênia Celso fazem-se presentes tempos de melancolia, outros de promessas que não se cumpriram, assim como se revelam ainda duradouros laços de uma relação familiar intensa, criada entre os membros do Colégio Sion, em São Paulo. Tudo parece interligar múltiplas temporalidades: passado, presente e futuro. A representação individual se ancora em construções de uma memória mais ampla, expressas pelas meninas que freqüentaram esse ambiente educacional e, posteriormente, retornam no imaginário com lembranças saudosas - "os brinquedos da minha saudade" dos tempos passados, povoados da cumplicidade, das relações imbricadas a cada instante dentro daquele universo. 
A autora tece a urdidura da memória carregando-a de condicionais, de tempos pretéritos que se entrelaçam, confusa ainda sobre seu papel neste mundo novo que se descortinava através dos ensinamentos cristãos, do perfume de santidade que envolve a Virgem Maria, modelo de Mãe, de mulher, de fé e de resignação para as jovens a quem a Fé (“crer”), a Esperança (“esperar”) e o "amor", traduzido pela Caridade, têm a eternidade sacralizada do dogma: "Foi ontem. É de hoje ainda. Será de sempre", numa certeza feita de esperanças de que o mundo fora do Colégio seja tão aninhador e tão disciplinado como o recôndito silêncio da "capelinha" do "meu velho Sion". A experiência feminina que mal começa a se constituir através de furtivos clarões naquele claustro de saber escolástico é prenhe de questionamentos.

Ao selecionar e recuperar algumas memórias e tentar apreender instantes de tempos vividos nos interiores do Sion, captando o evento, fundindo os horizontes (meu e das memorialistas), numa experiência hermenêutica de reconstrução histórica, valho-me de referenciais metodológicos de amplo espectro, uma vez que a própria temática assim o exige, sem delimitações por esta ou aquela tendência historiográfica, acolhendo idéias assim como colho lembranças; utilizando os métodos mais compatíveis com as fontes que se entrelaçam neste estudo.

Num contexto em que a educação mostra-se como uma forma de distinção ou meio de ascensão social, um dos instrumentos privilegiados que utilizo para dialogar com as representações é a memória, "propriedade de conservar certas informações", 2 tomando emprestado de Jacques Le Goff seu conceito. Lembrar direciona o olhar, o sentimento, a razão, além de ser responsável pela atualização de experiências vividas, de impressões, de informações passadas. Talvez aqui resida, segundo Pierre Nora, o fundamento da oposição entre História e Memória.

A memória é a vida, sempre carregada por grupos vivos e, nesse sentido, ela está em permanente evolução, aberta à dialética da lembrança e do esquecimento, inconsciente de suas deformações sucessivas, vulnerável a todos os usos e manipulações, suscetível de longas latências e de repentinas revitalizações. A história é a reconstrução sempre problemática e incompleta do que não existe mais. A memória é um fenômeno sempre atual, um elo vivido no eterno presente; a história, uma representação do passado. Porque é afetiva e mágica, a memória não se acomoda a detalhes que a confortam; ela se alimenta de lembranças vagas, telescópicas, globais ou flutuantes, particulares ou simbólicas, sensível a todas as transferências, cenas, censura ou projeções. A história, porque operação 
intelectual e laicizante, demanda análise e discurso crítico. A memória instala a lembrança no sagrado, a história a liberta, e a torna sempre prosaica. ${ }^{3}$

Recobrando as memórias das personagens sionenses que preservaram os "restos selecionados" de um passado que vivenciaram, emprestando valor a fatos que em outro contexto seriam meros acontecimentos triviais, reconstruindo momentos que marcaram vidas, escutando os sons que povoaram os silêncios do senhorial casarão da Avenida Higienópolis, onde estiveram presentes ao longo de quase um século de atividades e benfeitorias oferecidas pelas religiosas à comunidade paulistana, é possível descortinar a própria urdidura da história movediça da cidade em um momento de tensões sociais. A mesma cidade - espaço de valores e posturas mais burguesas - que separou ideologicamente os papéis sociais em apropriadamente masculinos e femininos prescreveu deveres às mulheres de modo a confiná-las em esferas específicas de atuação conveniente: o lar, a família.

Lembranças, sejam elas femininas ou masculinas, que no crivo do sujeito memorizador mereceram ser preservadas são, antes de mais nada, vivências selecionadas, ou seja, uma escolha pessoal do que vai ser lembrado e esquecido. Conforme indicou Moses Finley, preservar e transmitir lembranças não é um ato "espontâneo e inconsciente, e sim deliberado, com a intenção de servir a um fim conhecido pelo homem que o executa". O resgate da memória trabalha com as possibilidades de que os dados "individuais da tradição eram confundidos, modificados e, às vezes, inventados ... E, quando a tradição é inteiramente oral, torna-se bem mais simples confundir e falsificar. Na realidade, isso é inevitável". ${ }^{4}$

A memória é saturada de construções imaginárias e de projeções de "ego" ${ }^{5}$ que na maioria das vezes não se coadunam com a "veracidade" dos fatos, embora postule um compromisso com o que de fato aconteceu.

Lembrar implica um duplo movimento, conforme escreveu Marina Maluf:

acionar a memória para recapturar o passado e selecionar os eventos vividos ... Além disso, o ato pessoal de pensar o passado - de contar uma vida - está enganchado na trama coletiva da existência social. E a memória pessoal transforma-se em fonte histórica justamente porque o indivíduo está impregnado de elementos que ultrapassam os limites de seu próprio corpo e que dizem respeito aos conteúdos comuns dos grupos aos quais pertence ou pertenceu. ${ }^{6}$ 
A História se faz nas múltiplas temporalidades e nas realizações da liberdade humana. O tempo histórico ajuda a valorização do presente.

Comecei a sentir com maior agudeza, quase dolorosa, a individualidade de cada tempo ... que me fazia sentir o que chamo de "nostalgia prévia" de cada fragmento do tempo. Sentia com força a evidência, ainda que tudo continuasse ou se repetisse quase sem variação. Aquele tempo preciso que ali estava, passaria e não voltaria: poderia ser talvez muito semelhante, mas seria outro. ${ }^{7}$

A questão da reconstrução de outros tempos através da memória (no caso específico, lembranças de mulheres paulistanas durante as primeiras décadas do século XX) remete, necessariamente, às reflexões de Maurice Halbwachs sobre as relações entre memória individual e memória coletiva. A memória individual "é uma condição necessária e não suficiente do ato de lembrar", daí a necessidade de reatar os fios que tecem os intercâmbios e nexos entre o que parece ser de foro pessoal, particular, e aquilo que é claramente de cunho coletivo.

Porque, de acordo com Halbwachs, se a

primeira lembrança foi suprimida, se não nos é mais possível encontrá-la, é porque, desde muito tempo, não fazíamos mais parte do grupo em cuja memória ela se conservava. Para que nossa memória se auxilie com a dos outros, não basta que eles nos tragam seus depoimentos: é necessário ainda que ela não tenha cessado de concordar com suas memórias e que haja bastantes pontos de contato entre uma e as outras para que a lembrança que nos recordam possa ser reconstruída sobre um fundamento comum ... É necessário que esta recordação se opere a partir de dados ou de noções comuns que se encontrem tanto no nosso espírito como no dos outros, porque elas passam incessantemente desses para aquele e reciprocamente, o que só é possível se fizeram e continuam a fazer parte de uma mesma sociedade. ${ }^{8}$

Ao selecionar memórias femininas não estou delimitando o tema apenas por um enfoque de gênero. James Fentress indicou uma trilha para esse percurso, considerando que as mulheres "têm voz própria e é freqüente verem-se enredadas pelo facto de os principais estilos narrativos que conhecem para comemorar o passado se aplicarem a actividade masculinas". Acrescenta que ao contar histórias/memórias, as mulheres enfatizam muito os aspectos da vida doméstica e familiar, pois cabe a elas a "responsabilidade de encapsu- 
lar (purificar, moralizar) os registros da experiência passada para as crianças, como parte do processo de sociabilização".

No corpo documental pesquisado, manifesta-se a preocupação com o lembrar, tornar presentes os momentos que grifaram as experiências cotidianas daquelas moças que, resguardadas pelos muros de pedra do Colégio, preparavam-se para a vida iniciando-se no desempenho dos papéis sociais a elas destinados, trocando confidências menineiras com suas iguais, armazenando no baú das recordações os fatos que, assumindo cores de um passado feliz e descompromissado, seriam muitas vezes transmitidos às suas filhas e netas, revivendo-os como reviviam a juventude perdida, as tranças infantis substituídas pelo outono nos cabelos e nas almas, a segurança do Colégio trocada pelas incertezas do mundo "moderno", modo como se referiam as meninas aos novos tempos. Maria Eugenia Celso ao regressar ao "velho Sion" afirma não saber "se todas o verão como eu via", indicando certo saudosismo e a possível dúvida com relação aos ensinamentos apreendidos.

Outro aspecto da memória coletiva desse grupo é o fato de, regularmente, utilizar o plural nas referências ao passado comum - "O nosso coração se enche de entusiasmo e alegria..." - e ao "tempo feliz de nossa adolescência estudiosa”, como se isto justificasse a aplicação de normas, de costumes, do dever ser homogeneizador para essas mulheres em formação. Vitória Helena de C. Ramos, antiga aluna, me permite adentrar os tempos colegiais:

Preciosas horas felizes ... O nosso coração se enche de entusiasmo e de alegria, na certeza de que em breve, terminado o nosso curso, na dispersão inevitável de colegas que cresceram, estudaram, e viveram juntas tantos annos, a amizade dos bancos do colégio há de perdurar e iluminar a nossa estrada.

Ao encerrar, recomenda às parceiras: "guardaremos, como as antigas, recordação indelével do tempo feliz de nossa adolescência estudiosa; assim, traremos um dia as nossas filhas, para continuarem a cadeia ininterrupta, que liga a Sion cincoenta gerações de brasileiras". ${ }^{10}$

Para criar essa idéia de continuidade - "cadeia ininterrupta" - e perseverança das ideologias vigentes (ou que se queriam implantar), era necessário construir aparatos disciplinares que visavam "não unicamente o aumento de suas habilidades, nem tampouco aprofundar sua sujeição", mas a formação de uma relação de obediência. $\mathrm{O}$ ambiente escolar é um dos espaços privilegiados onde a disciplina encontra lugar fértil para o seu desenvolvimento. Como exemplo disto, está a própria educação cristã, repleta de regulamentos, 
inspeções e vigilâncias elaboradas para serem divulgadas dentro das "cercas" dos colégios e dos conventos, "lugares determinados que se definem para satisfazer não só à necessidade de vigiar, de romper as comunicações perigosas, mas também de criar um espaço útil". ${ }^{11}$

As questões de ordem, disciplina e higiene estavam presentes já no momento da admissão das alunas nos cursos ginasianos, quando então se ditavam regras a serem obedecidas. No "Regimento Interno" aparece a efetivação desses ideais: o Colégio

admite alunas internas e semi-internas. Não recebe:

a) portadoras de moléstias contagiosas ou infecto-contagiosas.

b) alunas que necessitam de tratamentos especiais em consultórios médicos ou dentários que obriguem a saídas freqüentes ou prolongadas que prejudiquem os estudos.

Quanto à disciplina, observam-se as seguintes prescrições:

A Diretoria e os Professores envidam esforços para que no Estabelecimento reine boa disciplina, condição indispensável para o desenvolvimento moral e intelectual das alunas. Esta Disciplina será sempre revestida de carinho, levando as educandas ao cumprimento do dever pela persuasão ... Para o bom êxito dos seus esforços a Diretoria procura obter uma intensa e inteligente colaboração com os Srs Pais. (Regimento Interno, 9 nov. 1940, fls. 1/2, grifos meus)

Era importante estabelecer "as presenças e as ausências, saber onde e como encontrar os indivíduos, instaurar as comunicações úteis, interromper as outras, poder a cada instante vigiar o comportamento de cada um, apreciálo, sancioná-lo, medir as qualidades ou os méritos" (Foucault, 2005, p.126131). Não é por acaso que, nas horas livres, as alunas de Sion estivessem sempre sob os olhares vigilantes e atentos das religiosas.

Era o sistema pedagógico criador de uma mentalidade nova, misto de disciplina e de afeto, tão absolutamente oportuno à nossa desordenada imprevidência e à prodigalidade excessiva de confiança de um povo jovem, a maneira direta de falar aos corações, de abri-los, de conhecê-los, de, principalmente, neles inocular os princípios das virtudes imprescindíveis. ${ }^{12}$

Contudo, os tempos de disciplinar/docilizar as mentes e os corpos femi- 
ninos não se restringiam aos momentos de lazer onde os movimentos e ações, aparentemente, estivessem livres. $\mathrm{O}$ dia, as horas, os minutos estavam organizados de maneira a manter a ordem e a disciplina. Deste modo, as normas da Igreja (que asseguravam a formação das "mulheres católicas” e das "boas cidadãs") estariam em vigor continuamente:

O sino supria o relógio. Era pela sua advertência que, automaticamente, se regulava o mecanismo do Colégio: aulas, recreios, estudos, preces, refeições. Havia momentos em que a gente lhe odiava a injunção, outros, em que o seu bater representava uma libertação, ansiosamente, esperada. ${ }^{13}$

A arte de dispor em fila dá início, já no século XVIII, à delimitação de espaços e às demarcações dos papéis cabíveis a cada indivíduo dentro dos ambientes escolares. "Filas de alunos na sala, nos corredores, nos pátios; colocação atribuída a cada um em relação a cada tarefa e cada prova; colocação que ele obtém, de ano em ano; alinhamento das classes de idade umas depois das outras; sucessão dos assuntos ensinados, das questões tratadas seguindo uma ordem de dificuldade crescente" (Foucault, 2005, p.134). Os dados apresentados por Foucault para o estudo de instituições do século XVIII apontam alguns elementos ainda vivos nas memórias das enfants de Sion, como é o caso de Lavínia Camargo, ex-aluna da turma iniciada em 1929, que relata:

Ao acordar, tínhamos uma série de obrigações e às 7:30 hrs deveríamos estar em fila na entrada do grandioso refeitório para a inspeção matinal. Era nessa hora que se observava, atentamente, a higiene, o asseio, o esmero dos uniformes e a ordem das meninas ... as que cumpriam suas obrigações, sempre eram mencionadas com distinção, servindo de exemplo às desordeiras e indisciplinadas. (Depoimento de Lavínia Ribeiro do Valle de Camargo. São Paulo, abr. 1995, grifos meus)

Estar “em fila” para a "inspeção matinal” remete à idéia desenvolvida por Foucault, que vê nessa regra disciplinar uma forma de organizar o múltiplo, isto é, um instrumento eficaz que permite dominá-lo. Nos diversos depoimentos e narrativas que compõem o universo das mulheres educadas no Sion as reminiscências da ordem, das filas e das inspeções inferem o ideal introjetado da vigilância disciplinar. Para se criar a "cadeia ininterrupta", abarcando "gerações de brasileiras," era fundamental estabelecer além de normas, modelos comportamentais. A prática educacional de caráter religioso esmeravase tanto nas regras quanto nas punições e na vigilância em todos os ambien- 
tes escolares: desde as salas de aula até os refeitórios, pátios e dormitórios. Esta ordenação das meninas mostrava-se eficaz na constituição de escolares distinguidos.

Nas instituições religiosas femininas, escreveu Etelvina Trindade, o ensino se encontra permeado pela doutrina cristã, expressa nas práticas do dia-a-dia:

a oração freqüente, antes ou depois de cada ato escolar, consubstanciada em fórmulas, jaculatórias e ladainhas; a preparação rigorosa para a Primeira Comunhão solene e o ato de confissão; os retiros espirituais periódicos, onde as participantes são convidadas a inspecionarem com todo o rigor a própria vida. É uma pedagogia da proibição e da punição. ${ }^{14}$

\section{UM LUGAR DE MEMÓRIAS: A EDUCAÇÃO}

Somente quem soubesse considerar o próprio passado como fruto da coação e da necessidade, seria capaz de fazê-lo, em cada presente, valioso ao máximo para si. Pois, aquilo que alguém viveu é, no melhor dos casos, comparável à bela figura à qual, em transportes, foram quebrados todos os membros e que agora nada mais oferece, a não ser o bloco precioso, a partir do qual ele tem de esculpir a imagem de seu futuro.

Walter Benjamin

Até a década de 1920, quando a preocupação passou a ser a "educação para todos", a escola fazia parte de um quadro de privilégios e de status para aqueles que podiam usufruir dela; significava não só o local do saber, como também o locus de formação cultural, científica e moral. O período em apreço assinala a constituição de um processo histórico de delimitações e de formulação de projetos no campo sociocultural, em particular no sistema educacional e médico-sanitarista, com a finalidade de acelerar o processo de produção da consciência pedagógica nacional e nele a constituição de uma ideologia educacional no país.

Foi uma época de articulações dos diversos setores sociais para a superação da crise da economia agroexportadora, além das contradições particulares da industrialização nacional e das campanhas do Estado para promover a consolidação do sistema capitalista. Compreende-se nesta fase a afirmação dos matizes sociais advindos do período anterior: concentração de riquezas, 
poderes e prestígio social destinados a camadas dominantes. Insere-se neste quadro a proposição de que era necessário impor limites e 'instruir' as classes dominantes para que pudessem administrar a nova ordem social que se configurava.

Outra hipótese era a de que o sistema educacional mostrava-se como uma possibilidade de romper com os obstáculos ao desenvolvimento econômico e social do país, pois a escola atendia aos propósitos de progresso individual e de mobilidade social (distinção), representados nos ideais escola-novistas. No entanto, as modificações demonstraram uma maneira de direcionar as insatisfações sociais, levando-se em conta que expandir as oportunidades educacionais ou reformar as instituições escolares representava um custo menor que alterar a distribuição de renda e as relações de poder. A pedagogia da Escola Nova apontava, neste sentido, a realização dos objetivos das classes dominantes, além de atender aos anseios das camadas intermediárias e inferiores. Sob a influência do pensamento liberal de John Dewey, a proposta escola-novista funcionava como um instrumento privilegiado de mediação política.

Os debates acontecidos entre as décadas de 1920 e 1930 contaram com a participação de diversos segmentos sociais, dentre estes os adeptos de idéias revolucionárias, reformistas ou reacionárias. O ponto de convergência entre esses elementos era a promoção urgencial da reconstrução do país através da escola, e os planos inovadores configuravam a vontade de "republicanizar a República" ${ }^{15}$ - entendida como modos de adequação/adaptação da sociedade brasileira aos novos moldes socioculturais. Somente após 1920 é que alguns focos reformistas, em âmbito estadual, foram postos em prática.

O soerguimento moral da nação brasileira deveria se dar através da educação, pois "a ignorância reinante é a causa de todas as crises; a educação do povo é a base da organização social", e somente tendo como premissa este projeto educacional é que o homem e a mulher brasileiros seriam recuperados e, conseqüentemente, assumiriam a sua função social, caracterizando-se como elementos "regeneradores de toda a sociedade". ${ }^{16}$

Retomo os pressupostos assinalados no "Manifesto dos Pioneiros da Educação Nova" - texto que reflete o pensamento liberal da Escola Nova - que afirma ser a educação um campo vasto, não restrito ao espaço escolar.

A educação não se faz somente pela escola, cuja ação é favorecida ou contrariada, ampliada ou reduzida pelo jogo de forças inumeráveis que concorrem ao movimento das sociedades modernas ... Há a herança que é a escola da espécie; 
a família que é a escola dos pais; o ambiente social que é a escola da comunidade, e a maior de todas as escolas, a vida, com todos os seus imponderáveis e forças incalculáveis. ${ }^{17}$

As expressões pedagógicas e os inflamados embates educacionais que se travam no período demonstram a importância da educação para o desenvolvimento moral do país. Neste contexto, a Igreja católica encerra-se também num processo de rearticulações internas, uma vez que se apresentava a urgência de mobilização de seus representantes para a "cruzada vencedora" que impediria o país de continuar na "ignorância religiosa". Por conseguinte, formar cidadãos católicos, em especial "mulheres católicas" - sinônimo da mulher brasileira ideal -, tornava-se elemento crucial aos propósitos ideológicos da Igreja e do Estado. Essa visão pode ser detectada nas cartas eclesiásticas de D. Sebastião Leme, em Carta Pastoral de 1916, que informa a necessidade de "transformar a maioria nominal (de católicos) em força influente nos destinos do País, por meio da difusão da verdadeira instrução religiosa e do desenvolvimento da ação social católica, de modo a formar uma cruzada vencedora contra a descrença que assola e devasta a organização da Pátria”. Sampaio Dória compartilha das opiniões elencadas por D. Leme, afirmando que o Brasil, "na opulência de seus thesouros e de sua gente de valor racial, requer da escola, e della espera, o apparelhamento das gerações novas para as virtudes democráticas". ${ }^{18}$

A Igreja articula através dos discursos de seus integrantes os meios pelos quais se apresentará como instrumento relevante para o soerguimento nacional. Apesar da separação entre Igreja e Estado ter sido definida legalmente pela Constituição de 1891, ambos caminham juntos na modelagem e no processo de sedimentação das regras impostas pelas novas circunstâncias sociais. Talvez este seja um ponto até então não definido, pois é nesse momento que se acirram os combates para a inclusão do ensino religioso no setor público. Ademais, note-se que é também nesse período que a "cristianização da inteligência brasileira", consoante $\mathrm{D}$. Leme, se torna alvo primordial das atividades da Igreja católica, destacando-se o aparecimento da revista A Ordem assim como de outras publicações e congressos realizados para esse fim.

Uma das maneiras encontradas pela Igreja para cumprir seus propósitos é abrir novos terrenos apropriados para a cristianização, e para isso as congregações, especialmente as atentas à educação do sexo feminino, recebem aval para penetrar nas grandes cidades brasileiras e impor normas e perfis para as mulheres que serão mais tarde promotoras dos ideais e das virtudes ca- 
tólicas. Neste sentido, a educação para moças começava a "adquirir um significado e importância maiores, e as congregações religiosas, neste aspecto, ocuparam papel relevante, entre elas, as de origem francesa". ${ }^{19}$

A preocupação e o compromisso do fazer História sugerem que "nada do que aconteceu deve ser perdido para a História ... só à humanidade redimida o passado pertence inteiramente". ${ }^{20}$ Portanto, este artigo está orientado pela idéia de resgatar as memórias femininas que se alojaram numa instituição religiosa de ensino, ou pelo menos estiveram vinculadas a ela - o Colégio Nossa Senhora de Sion, fundado por uma congregação francesa -, além de traçar os matizes das mulheres das elites do período em questão.

A escolha do tradicional colégio paulistano é explicada por sua progressiva secularização, por ter sido responsável pela formação e orientação de tantas jovens, não só da cidade de São Paulo, como do interior do estado, ou até mesmo de outros estados próximos.

Os anseios e os objetivos da Congregação relacionados com a educação feminina podem ser extraídos dos textos deixados por Claude Mondésert em 1956, acerca das obras realizadas pelas religiosas e que procuravam denotar os caminhos destinados às "mulheres católicas", sem deixar de ocupar-se da instrução das enfants para os intentos e obras da Cristandade. As religiosas de Sion

consagram-se a diversas obras e particularmente à educação e à instrução de meninas, quer nos países antigos da Europa, onde a situação de ensino livre, às vezes complexa, não diminui em nada a fecundidade, a utilidade e até a urgente necessidade das escolas cristãs, quer, sobretudo, nos países novos, onde se verifica que esse trabalho é indispensável e fundamental para a consolidação de uma cristandade mais recente. ${ }^{21}$

Nesse trecho enuncia-se o momento exato para a estabilização da cristandade nos "países novos", em caráter de "urgente necessidade", pois neles, a sociedade ainda não se apresenta totalmente configurada e, portanto, a introdução de normas e de valores cristãos poderia encontrar terreno fértil e de rápida assimilação, acrescentando os papéis funcionais de cada indivíduo para que este se enquadrasse na noção de "operosidade" tão difundida pelos modelos e prescrições católicos.

Ademais, o processo civilizador cristão visava ao alargamento e à sedimentação dos princípios que até meados do século XIX não haviam sido explorados no Brasil de forma tão veemente. Com esse intuito é que a Congre- 
gação Sionense inclui-se na campanha de modelar/civilizar as sociedades "inacabadas", "onde se verifica que esse trabalho é indispensável".

Uma consolidação provisória delineava o processo vivenciado pela sociedade brasileira e, por esta razão, as religiosas se empenharam em introduzir os fundamentos da "regeneração" do país e da fé católica. Portanto, a relevância do colégio - e de sua pedagogia - afinavam-se em inúmeros pontos com o projeto civilizador proposto pelos intelectuais da Escola Nova. O relatório do inspetor federal Arlindo Drummond Costa (1933) enfatizava a importância da Instituição na vida paulistana e sua responsabilidade pelos resultados que poderiam ser atingidos através da educação cristã:

As dignas religiosas dirigentes deste estabelecimento de ensino - que tanto honra as forais da cultura patrícia - tornaram-no um verdadeiro santuário da operosidade educativa. Eis porque, professor há quinze anos, expontânea [sic] e prazeirosamente $[s i c]$, aqui deixo os meus merecidos aplausos à benemérita Diretoria $\mathrm{e}$ a digna Inspetoria do Colégio Notre Dame de Sion - vanguardeiro dos estabelecimentos congêneres femininos. (Livro de Inspeção Federal, 22.12.1933, p.25)

A "operosidade educativa” manifesta no texto denota a função social que o Colégio Sion deveria se empenhar em alcançar: ser um "vanguardeiro", assegurar a formação das mulheres para cumprir, perfeitamente, o papel de "esposas e mães católicas”, responsáveis pela primeira educação de seus filhos. Este caráter promotor das práticas femininas era tido como sustentáculo do labor católico na consolidação do civismo e das virtudes prescritivas, veiculadas para a mulher brasileira e, especialmente, para a paulista.

A mulher instruída com solidez não poderia ser um peso para o seu marido ou pai, um fardo para a sociedade; mas, sim, um braço forte que lutava com dignidade e altivez para a felicidade da família e para orgulho da Pátria ... Alguém dizia que instruir a mulher é preparar as gerações do futuro ... porque é justamente pela instrução da mulher que se começava a do homem... (Depoimento de Lavínia Ribeiro do Valle de Camargo. São Paulo, abr. 1995)

De acordo com Maria Odila Leite da Silva Dias, o surgimento de colégios como os confessionais "contribuiu para difundir tanto através dos livros escolares como das lições de etiqueta, a adoção de novos costumes, entre os quais a idéia da mulher rainha do lar e totalmente dedicada aos filhos". Tal ta- 
refa foi secundada pelas revistas femininas que se incumbiram de receitar as melhores regras para as mulheres cumprirem seu destino doméstico.

A instrução recebida, portanto, animava as mulheres em suas funções de espelhar "dignidade e altivez" não só em relação à família, como também ao seu país. Sua "vida-missão" estava definida: cabia a ela a formação das gerações posteriores e por este motivo deveria empenhar-se em sua própria preparação. Este ideal já era proclamado no século XIX em algumas revistas. Assim escreveu uma colaboradora de A Mensageira:

Não basta que comprehendamos a utilidade e os attractivos do espírito cultivado, é mister que façamos de nossa parte o maior esforço possível, procurando instruir-nos e desenvolver-nos a bem da pátria e da família ... Quanto mais illustrada e intelligente for uma mulher, tanto mais zelosa e cumpridora de seus deveres será ...22

\section{VIDA-MISSÃO: A CONSTRUÇÃO DE PERFIS E MODELOS FAMILIARES}

Ao lado da idéia de "vida-missão", corre a noção de "pertencer a", ou seja, de que a moça educada em um colégio congregacional faz parte de um grupo privilegiado de pessoas, encarregadas da transmissão e preservação de valores, crenças, regras, e até mesmo de certa cumplicidade juvenil que, como fio colorido retece as memórias, dando a elas uma semelhança de colcha de retalhos, momentos gravados no tempo que cumpre preservar do desgaste que o mundo fatalmente lhes imporá. É assim como se as "classes multicores" fossem confrarias de jovens, formadas pelos mesmos padrões, vivenciando as mesmas ansiedades, trocando experiências e segredos que as irmanavam para sempre.

Em um trecho do "Caderno de Poesias", datado de 1942, a ex-aluna Benedita Mendes Vieira menciona um almoço ocorrido no aniversário da formatura da Classe Multicor de 1927 - a seriação do Colégio Sion estava nomeada por cores e a classe referida correspondia ao último ano do ginásio. Nesse informe, a autora elenca saudosamente todas as convidadas que estiveram presentes à reunião: Alices, Lucias, Edites, Lauras, Camilas, entre tantas outras, que "não pode por deficiência de espaço, mencionar", fazem parte desta imagem produzida num momento de "belas recordações".

Dia de história inesquecível! História bonita para contar à lareira, quando caírem sobre as meninas de Sion de hoje, as primeiras geadas do inverno. Quando 
saí, à luz doirada da tarde, pareceu-me notar que na fronteira do colégio, em seu nicho de pedra, morena pelo tempo, N. S. de Sion sorria satisfeita por ver de volta ao ninho antigo, como andorinhas aos beirais, tantas "florinhas" que o vento forte da vida soprara para longe!

A função de transmitir experiências felizes está introjetada, indicando um acolhimento de um dos papéis que cabia à mulher - propagadora da missão católica e provedora do núcleo fundamental da vida feminina: a família, unidade sacralizada pela Igreja católica. Apesar de muitas vezes afastada da grande família sionense pelo "vento forte da vida", suas filhas retornam "ao ninho antigo" nos momentos de aflição e de alegrias para renovar ou firmar as normas por tantos anos ensinadas.

A proposta de manter a identidade das alunas através de suas reminiscências é demonstrada na preocupação de mantê-las sem que mudanças de qualquer tipo pudessem abalar seus sólidos referenciais. Isto pode ser percebido nas interlocuções entre as meninas, principalmente nas deixadas sob forma de cartas e diários dos tempos escolares que descrevem "os dias saudosos vividos sob o teto acolhedor de Sion...", 23 aclamado como espaço de segurança, local de proteção e refúgio dos males que afligem o "mundo moderno". Afinal, era necessário manter "o verdadeiro alento na formação da Congregação das Mães Cristãs, regeneradoras da família católica”, além do empenho e dedicação assíduos para "cultivar as almas e os corações das moças, reunidas na Congregação das Filhas de Maria”. ${ }^{4}$

Numa "Carta Aberta" dirigida a Camilla Barbosa de Oliveira, Benedita Mendes Vieira, elogiando o discurso proferido por "Camillota", na ocasião do centenário do aparecimento da Virgem Maria ao fundador da Congregação sionense, relembra as frases pontuais da fala da colega:

Um folhear de páginas ressumadas de saudades no livro de nossa lembrança e uma saudade das saudades que tivemos. Dizeis bem: haverá cousa mais gostosa que relembrar? Abrigadas à sombra dessa árvore frondosa que brotou, cresceu, floriu e frutificou sob os olhares de Maria, aqui revivemos, por alguns instantes, a nossa meninice despreocupada, fugimos ao torvelhinho da vida atual que muitas vezes nos franze a testa do que nos faz sorrir ... Tens razão, querida Camillota, recordar é bom! melhor, porém, é sentir ainda viva a chama do amor sionense, lume que nos aquece e nos aclara a vida, estrela que nos ilumina o caminho da existência... ${ }^{25}$ 
A recordação vem com toda sutileza explicitar as prescrições, reafirmando os papéis adstritos às mulheres "educadas". É esse sentido de memória "estrela que nos ilumina" - tecendo um entrelace de lembranças compartilhadas coletivamente - "lume que nos aquece e nos aclara a vida" - de momentos que se tornam importantes em decorrência de um referencial comum - mesmo sexo, mesma faixa etária, mesma classe e status, mesmos objetivos e até as mesmas crenças, têm o poder de "individualizar", fazendo que as memórias que são de muitas possam ser tomadas como a memória de cada uma das meninas de Sion. O tempo encarregando-se de fundir recordações, elidir diferenças, somar saudades.

ENTRE O INDIVÍDUO E O COLETIVO: DIRETRIZES NA FORMAÇÃO IDENTITÁRIA DE MULHERES

Quase sempre elementos ficcionais, profundamente subjetivos, acabam interferindo no processo de formação da memória, fazendo que personagem/personagem (no sentido de criado/vivido), se confundam e tornem-se um amálgama difícil de ser desconstruído, ou pelo menos, que se possam vislumbrar seus territórios fronteiriços.

Os eventos que marcaram a participação do corpo docente e discente; as lembranças das antigas alunas; a sede do "saber humanístico" das mulheres de elite; as representações e entraves aportados pela vida social e política da cidade; os dissabores enfrentados com as epidemias e transformações ocorridas no âmbito nacional e citadino, sem abandonar os abalos internacionais, são "reminiscências puras que ficaram a rebrilhar", infiltradas na grandiosa arquitetura, nos jardins, nas indeléveis marcas que o tempo deixou em suas paredes e no próprio silêncio carregado de "souvenires da grande família de Sion".

São as palavras de Maurice Halbwachs que me servem para traçar os territórios limítrofes entre a memória individual e a memória coletiva. As primeiras recordações que vêm à tona quando se refere às construções memoriais de um determinado grupo são "dos acontecimentos e das experiências que concernem ao maior número de seus membros" e que, de alguma forma, "resultam quer de sua própria vida, quer de suas relações com grupos mais próximos". Deve-se atentar ainda para o fato de os indivíduos pertencerem a um grupo; portanto, 
a memória coletiva tira sua força e sua duração do fato de ter por suporte um conjunto de homens ... Dessa massa de lembranças comuns, e que se apóiam uma sobre a outra, não são as mesmas que aparecerão com mais intensidade para cada um deles. Diríamos voluntariamente que cada memória individual é um ponto de vista sobre a memória coletiva, que muda conforme o lugar que ali eu ocupo e que este lugar mesmo muda segundo as relações que mantenho com outros meios. (Halbwachs, 1990, p.45-51, grifos meus)

Esta citação me aproxima de algumas recordações escritas pelas jovens, cujo traço é reviver/recolorir os tempos de peraltice e de responsabilidade, ainda que somente ligadas às atividades desempenhadas no ambiente escolar. Freqüentemente, deixam relatos e descrições de tempos vividos, de instantes de prazer e honra.

O próprio tempo assina seu nome nas lembranças das "martinhas" singelas (jovens bolsistas), das irmãs e das ex-alunas que carregam uma saudade enorme do momento que viveram protegidas e resguardadas pelos muros do Colégio, sonhando vidas tão diferentes entre si - como a simplicidade monástica do convento e o fausto dos grandes salões da elite paulistana ou de recitais e eventos culturais que exigiriam a "educação de sala" onde, certamente, as "antigas" do Sion, como categoria elitizada, deveriam brilhar.

O velho relógio ao pé da escadaria testemunhou, solene, horas alegres e lágrimas sentidas. Seu tique-taque monótono "passado/presente/passado/presente" ditava o inexorável passar, o escorrer de instantes que, se um dia tiveram um significado, são eles o norte de minha busca.

Walter Benjamin, ${ }^{26}$ fazendo uma leitura da obra de Proust, assinalou que o autor de "Un amour de Swan" não escreveu exatamente o que aconteceu, mas sim aqueles instantes que deságuam, involuntariamente, sobre a mente e que não sofrem a coerção de limites. Enquanto a memória do lembrado é incontida, desliza solta ao sabor das críticas e dos cerceamentos de quem a tece - é involuntária -, o vivido é linear e traz consigo a idéia de ordenação das lembranças, de repressão, compelindo uma reformulação do fato, inserindo-o no rol dos momentos reconstruídos, muito mais do que no dos restituídos à luz.

Relembrei e vivi, envolta em saudades, as recordações daquelles bons tempos que não voltam mais ... Quantas recordações suaves e queridas da minha juventude confiante e crédula ... repleta, talvez, de sentimentalismo ... Naquelles tempos o cinema, os esportes, as praias ainda não nos haviam roubado o nosso romantismo, tão nosso, tão brasileiro ... Teria inconvenientes, não o nego ... mas 
fez de nossa mocidade um relicário de emoções encantadoras e de inolvidáveis recordações! ... Recordação! que palavra tão boa de se dizer! Há nella um fogo que lavra, reanimando-nos o ser. Recordação! tanto dizes! que, às vezes, chego a suppor que volto aos dias felizes de uma adolescência em Flôr... ${ }^{27}$

O "relicário de emoções" descrito nas reminiscências das alunas demonstra que não só o tempo presente deveria ser vivido e guardado por sua importância, por seus ensinamentos. As experiências apreendidas no Colégio deveriam sempre servir de guia, de foco de luz em momentos de aflições e no "torvelhinho [sic] da vida atual". Os preceitos católicos estariam sedimentados, cumprindo "as mulheres com seu dever para toda a vida". A "vida-missão" anunciada pela educação sionense creditava um papel primordial à mulher e, logo nos primeiros ensinamentos, consta que "no começo do ano letivo, deverá a Diretora comentar minuciosamente o Regulamento escolar, persuadindo as alunas de que este lhes fortifica a vontade, e delas fará mais tarde, mulheres de dever. Nenhum serviço iguala-se ao de formá-las no dever para toda a vida". 28

Com a função social de "formá-las no dever", para que pudessem cumprir seus papéis, o ideário sionense pode ser visualizado nas falas de suas alunas. Afinal, o

que fazem as meninas de Sion? Perdem as suas tardes em salas de cinema, em jogos de bridge ou nos tão afamados cockails parties? Não - mesmo aquellas cuja situação social as obriga a viver em festas - se dedicam, por pouco que seja, ao sentido profundo do que hoje a todos empolga: a Ação Social Católica. ${ }^{29}$

Nos seus estudos de egodocuments, Rudolf Dekker aponta os perigos que o historiador enfrenta ao lidar com memórias, autobiografias ou mesmo diários, mostrando que essas fontes, a serviço tanto da História como de outras áreas de conhecimento, são extremamente personalizadas, temperamentais. Resultado de um monólogo, produto de uma introspecção de quem escreve, de uma visão particular de um indivíduo sobre um momento pretérito de sua vida. Esses egodocuments devem ser lidos sempre como informes parciais, referências prismáticas de verdades mais abrangentes, embora sempre de grande utilidade para se vislumbrar as representações, os usos e os costumes da sociedade na qual estão inseridos. Há que se ter sempre em mente que o autor para escrever sobre um tema deve ter por ele um forte sentimento, seja de em- 
patia seja de antipatia, já que alguns escrevem para se reconciliar com seu passado, exorcizar angústias antigas ou aversão que sentem por suas personagens.

É esse cuidado de inventar e não mentir, de "traduzir, não trair", que se deve ter ao lidar com fontes: cada sinal, índice, símbolo, foto, texto, ou até mesmo as listas de alunas premiadas por alcançarem notas máximas nos trabalhos escolares, chegam até nós impregnados com os cheiros do passado, exalando o perfume que o tempo se encarrega de deixar nas folhas empoeiradas dos diários e cartas, prenhes de lembranças - "daqueles bons tempos que não voltam mais".

Arroubos de moças casadouras que se entrincheiravam atrás dos muros do velho casarão da Avenida Higienópolis à espera das durações de um tempo que se encarregaria de gastar os tijolos do edifício, escurecer a imagem de Nossa Senhora de Sion, localizada no pátio central, tornando-a escura como uma brasileira daquelas que se viam excluídas do convívio com as enfants de Sion, mas que poderiam ser piedosamente acolhidas entre as "martinhas": grafadas em letras minúsculas e lembradas no diminutivo.

Esse mesmo tempo encarrega-se de amenizar lembranças amargas, tornar mais doces ainda aquelas que um dia encheram de alegria as páginas do Ecos de Sion, que chegam até nós cheios de segredos escondidos nas entrelinhas inconfidentes de crônicas e de poesias menineiras. Ecos de um tempo que o tempo da lembrança se encarregou de "restaurar" e de "reconstruir", deixando que as lágrimas se transformassem em risos, que a alegria dos recreios, tantas vezes cantada, desse um tom róseo aos sóbrios quartos, refeitórios e outras dependências do Colégio registradas nas fotografias.

As imagens que revelam e que escondem os rostos femininos podem ser apreendidas a partir da perspectiva de que, para o historiador, "os sinais de vida latente, congelados numa fotografia são índices do mundo do passado que se busca compreender e podem se transformar em testemunho e representação de uma realidade a ser reconstruída”, conforme afirmou Davi Arrigucci Jr. ${ }^{30}$ Abro então caixas empoeiradas de fotografias do universo sionense para buscar pistas de memórias, de sinais que me remetem ao cotidiano das enfants. Salas imensas, corredores e carteiras escolares vazios, tudo parecia indicar ausência de qualquer tipo de "desordem do concreto".

Os estudos de Foucault expressam uma possibilidade de interpretação, baseada na construção do Panóptico de Bentham: "é visto, mas não vê; objeto de uma informação, mas nunca sujeito de uma comunicação”. Ou ainda, para explicitar melhor a função deste elemento que pode ser utilizado como "máquina de fazer experiências, modificar o comportamento, treinar ou re- 
treinar os indivíduos" (Foucault, 2005, p.177-180) a ver o que não pode ser visto. O material fotográfico do Colégio projeta sempre uma imagem ordeira e suntuosa da vida intra-muros, embora se tenha certeza de que nem sempre era esta a realidade vivida pelas meninas na escola.

De acordo com a análise feita por Jean-Paul Curnier, essas fotografias poderiam ser compreendidas como um "modo de parar o tempo", sujeitando as memórias a um vestígio real de uma experiência singular, mas que poderia servir de chave para qualquer aluna, pois o referencial era parte de uma memória coletiva. A documentação visual direciona uma determinada memória virtual, uma lembrança inventada, porque ela "sustenta em nós aquela impressão esquisita de familiaridade com o desconhecido. Por isso, cada fotografia, uma vez que compõe parte de nossa memória, é também, como parte, uma lembrança pessoal". ${ }^{1}$

Abre-se uma possível interpretação do conjunto fotográfico sionense: a idéia de temporalidades, de inculcar/plasmar memórias coletivas com base em imagens congeladas e sem referências pessoais explícitas. Deste modo, os retratos assinalavam uma parte essencial dos projetos implantados pela instituição: assegurar a sobrevivência no imaginário de cada uma e de todas de um dever ser contido nos ensinamentos.

Patrick Hutton elucida outro aspecto importante da reconstrução de experiências de vida a partir das lembranças pessoais. Houve um tempo em que a arte mnemotécnica consistia em ligar acontecimentos que se "desejava recordar a imagens que fossem de tal modo visualmente impactantes ou emocionalmente evocativas que pudessem ser relembradas de imediato". Tinha-se uma idéia de memória iluminada. Modernamente, a recordação passou a ser compreendida a partir de sua natureza construtiva. "Selecionam-se imagens do passado em virtude do que se julga importante do ponto de observação presente, para então entrelaçá-las tendenciosamente numa elaboração narrativa do processo de vida" ${ }^{32} \mathrm{e}$, neste sentido, as lembranças são pontos de referência, prisioneiras de uma determinada percepção da vida, resultado de um lugar de onde se fala.

Valendo-se dos estudos freudianos - especialmente a questão da memória encobridora - essa vertente proposta por Hutton aborda um lado pouco trabalhado pelos historiadores: o inconsciente, que enuncia a idéia de que os homens procuram esquecer, ao invés de lembrar, "pois é mais fácil viver protegido por um escudo de fantasias sobre os fatos de nossas vidas do que com a realidade". Esta visão, em muito, lembrou-me das passagens em que as "meninas de Sion" voltavam ao "acolhedor teto" do colégio para "esquecer o tu- 
multo da vida de tantas responsabilidades e intempéries ... como assumir as tarefas de casa, as rédeas da criação dos filhos, além de estar sempre atenta às necessidades das pessoas mais necessitadas", como relatou Lavínia Camargo (depoimento em abr. 1995).

A memória também persistia no jornal Ecos de Sion, imprimindo as palavras que ficavam reverberando nas experiências da vida adulta, vigiando as enfants para torná-las “senhoras funcionalmente distintas". A vida cotidiana fora da segurança do Colégio é freqüentemente anunciada nas reminiscências, como aquela em que ex-alunas já formadas relembram uma excursão ao sítio de repouso da congregação, em janeiro de 1942:

Bem se percebia que suas vinte e oito passageiras, esqueciam, por um dia ao menos, os cabelos grisalhos, os vincos com que as preocupações da vida lhes marcaram a fronte e, por algumas horas, revestiam de sua "caçulinha" ou quem sabe mesmo, da netinha mais velha. ${ }^{33}$

\section{NATUREZA E CULTURA: A MEMÓRIA IMPLANTADA E COLETIVIZADA}

A lembrança atinge outros sentidos: o olfato desencadeia um relembrar de missas, quando o incenso elevava "os corações ao alto" ao som de "tantun ergun sacramentun"; lembra ainda os passeios feitos a Atibaia ou Petrópolis, o cheiro da comida enfeitiçando os solenes refeitórios onde a soeur leitora, monotonamente, recitava uma edificante vida de santo ou passagem bíblica; lembra o chocolate quente nas manhãs de inverno; o cheiro dos corpos jovens, a "martinha" ajoelhada limpando os imensos corredores da memória, substituindo os odores da vida pelos do "sagrado" higienizado, lembrando velas acesas que tentam iluminar os caminhos para os céus para aquelas que teimavam em viver na terra.

"Momentos que ficarão perfumando o resto da vida, indifferentes ao desmoronar de todos os outros sonhos" (Ecos do Sion, n.15, jul. 1936, p.14). Estas recordações não são simplesmente partes integrantes de um passado, mas comportam "símbolos da família, dos laços de descendência, que podem ser transmitidos como bens que contem uma história". Os valores e as virtudes apreendidas na formação sionense foram constantemente evocados nas lembranças: Sion é a representação ideal de família, da família do espírito,

aquela cujos liames, por mais sutis, não deixam por isso de ser menos profundos e correspondentes a um sentimento mais arraigado e mais contentemente 
nosso ... É mais que um laço de sangue, a explicar tendências similares e mais ou menos niveladoras. É o ambiente que ultrapassa as aspirações do indivíduo e em que encontram clima os anseios da personalidade, na diferenciadora capacidade de ascensão e na possibilidade de ser cada vez mais, num sentido de nobreza e de suprema dignidade humana. ${ }^{34}$

Nessa proposta de estruturar uma família, o papel singular e paradigmático da "Mãe" é representado por Notre Mère. Rememorado o cotidiano das classes repletas de jovens, tementes quando

tocava a sineta de oito horas, entrávamos para as classes, e, feita a oração, ouvíamos o seu passo surdo e pesado, nas galerias. Vinha em cada classe, tomava conhecimento das notas diárias de procedimento e de aplicação. Depois, uma palavra enérgica de advertência às cabecinhas turbulentas, que andavam fora da lei; lindas palavras de animação às que trilhavam o caminho do dever. A mère, para nós, era uma força eterna. ${ }^{35}$

No âmbito da constituição da cidadania, a vigilância também aparecia com freqüência. Consoante Sampaio Dória, para ser um “bom cidadão” era fundamental estar atento às leis, às regras organizadoras da sociedade. Por isto a escola, considerada uma "espécie de república em miniatura", devia instruir seus alunos para que, "ao deixarem aquela, encontrassem, na vida pública, uma ampliação daquillo a que se habituaram", "um pequeno grande mundo" que deveria ser assim como um ensaio geral para se introduzirem as moças - no mundo real e desprotegido da sociedade, onde deveriam viver aplicando, na vida cotidiana, os ensinamentos recebidos.

\section{NOTAS}

${ }^{1}$ CELSO, Maria Eugenia. Reminiscências, 1942, v.2, p.100. (São Paulo, manuscrito, Arquivo do Colégio Sion de São Paulo).

${ }^{2}$ LE GOFF, Jacques. Memória. In: Enciclopédia Einaudi. 1. Memória - História. Lisboa: Imprensa Nacional/Casa da Moeda, 1984. p.11.

${ }^{3}$ NORA, Pierre. Entre memória e História: a problemática dos lugares. Projeto História, n.10, São Paulo: PUC-SP, dez. 1993. p.9.

${ }^{4}$ FINLEY, Moses I. Uso e abuso da História. São Paulo: Martins Fontes, 1989. p.21, 23. Ver 
também THOMPSON, Paul. A voz do passado: história oral. Rio de Janeiro: Paz \& Terra, 2002.

${ }^{5}$ Sobre a Ego-história ver: DEKKER, Rudolf M. Ego-Documents in the Netherlands 15001814. In: Dutch Crossing, a Journal of Low Countries Studies, n.39, 1989; DUBY, Georges. A vida continua. Rio de Janeiro: Zahar/UFRJ, 2003; PERROT, Michelle. Entrevista. Projeto História, n.10, dez. 1993; HOBSBAWM, Eric. A era dos extremos. São Paulo: Companhia das Letras, 2005.

${ }^{6}$ MALUF, Marina. Ruídos da memória. São Paulo: Siciliano, 1995. p.82.

${ }^{7}$ MARÍAS AGUILERA, Julian. Una vida presente. Memórias, I. Madrid: Alianza Editorial, 1988. p.217. (tradução minha).

${ }^{8}$ HALBWACHS, Maurice. A memória coletiva. São Paulo: Vértice, 1990. p.34.

${ }^{9}$ FENTRESS, James; WICKHAM, Chris. A memória social: novas perspectivas sobre o passado. Lisboa: Teorema, 1994. p.171-5.

${ }^{10}$ RAMOS, Vitória Helena de C. Reminiscências, v.2, p.134.

${ }^{11}$ Foucault demonstra que, no século XVIII, as disciplinas nascem para permitir um maior controle sobre os indivíduos, impondo-lhes uma relação de docilidade e utilidade. FOUCAULT, Michel. Vigiar e punir: história da violência nas prisões. Petrópolis: Vozes, 2005. p.126-8.

${ }^{12}$ GONÇALVES, Suzana. Fidelidade. Reminiscências, São Paulo, v.2, p.152.

${ }^{13}$ CELSO, Maria Eugenia. Reminiscências, São Paulo, v.2, p.124.

${ }^{14}$ TRINDADE, Etelvina. Clotildes ou Marias: mulheres de Curitiba na Primeira República. História: questões e debates. Curitiba: APAH, jul.-dez., 1990. p.23.

${ }^{15}$ Expressão usada por Jorge Nagle para se referir à campanha educacional vigente nas primeiras décadas do século XX. Educação e sociedade na Primeira República. São Paulo: EPU, 1976.

${ }^{16}$ NAGLE, Jorge. A educação na Primeira República. In: HOLANDA, S. B. História geral da civilização brasileira. Tomo III, Livro 3. São Paulo: Difel, s.d. p.263.

${ }^{17}$ AZEVEDO, Fernando (Org.). A reconstrução educacional do Brasil. Ao povo e ao governo. Manifesto dos Pioneiros da Educação. Rio de Janeiro: s.n., 1932. p.40.

${ }^{18}$ DÓRIA, A. de Sampaio. O que o cidadão deve saber. São Paulo: s.n., 1919. p.258.

${ }^{19}$ Discurso proferido pelo Secretário de Estado da Cultura, sr. Jorge da Cunha Lima, a propósito do tombamento do Colégio Sion, em novembro de 1986.

${ }^{20}$ BENJAMIN, Walter. Obras escolhidas: Magia e técnica, arte e política. São Paulo: Brasiliense, 1993. p.223.

${ }^{21}$ MONDÉSERT, Claude. As religiosas de Nossa Senhora de Sion, São Paulo: s.n., s.d. p.61. 
${ }^{22}$ A nossa condição. A Mensageira, São Paulo, n.4, 30.11.1897, p.49.

${ }^{23}$ Carta Pessoal de Benedita Mendes Vieira a Camilla Barbosa de Oliveira. São Paulo, 20.01.1942 (manuscrito - Arquivo do Colégio Sion).

${ }^{24}$ NATUZZI, J. Monsenhor Macedo Costa. Reminiscências, v.1, p.45.

${ }^{25}$ Carta Pessoal de Benedita Mendes Vieira a Camilla Brabosa de Oliveira. São Paulo, 20.01.1942 (manuscrito).

${ }^{26}$ BENJAMIN, Walter. A imagem de Proust. Obras escolhidas: Magia e técnica, arte e política, cit.

${ }^{27}$ JARDIM, Maria da Conceição de Moraes. O colégio Sion na capital de S. Paulo. Reminiscências, v.1, p.98.

${ }^{28}$ RATISBONNE, Pe. Teodoro. Cartas pessoais. São Paulo, s.d. mimeo.

${ }^{29}$ VIDAL, Mena Figueiredo. Que fazem as meninas de Sion? Echos de Sion, n.6, abr. 1934, p.146.

${ }^{30}$ ARRIGUCCI JÚNIOR, Davi. Prefácio. In: LEITE, Miriam Moreira. Retratos de família. São Paulo: Edusp, 1993. p.11.

${ }^{31}$ CURNIER, Jean-Paul. Memória de ruínas. Imagens, n.3. Campinas: Ed. Unicamp, dez. 1994. p.104-5. Para a análise de fotografias, ver também DUBOIS, Philippe. O ato fotográfico e outros ensaios. Campinas: Papirus, 1994.

${ }^{32}$ HUTTON, Patrick. The art of memory. Journal of the history of ideas, v.68, n.3, July-Sept. 1987, p.27, 43. (traduções minhas).

${ }^{33}$ BOTELHO, Anita de A. As ex-alunas em Atibaia. Ecos de Sion, n.28, jan. 1942, p.10-1.

${ }^{34}$ GONÇALVES, Suzana. Fidelidade. Reminiscências, v.2, p.151.

${ }^{35}$ BICALHO, Madalena Lacerda. Notre Mere Angelina. Reminiscências, v.1, p.50.

Artigo recebido em novembro de 2007. Aprovado em dezembro de 2007. 